DOI: https://doi.org/10.4796o/2303-7431.25.2021.21

UDK: 811.163.42'373:

Izvorni znanstveni članak

Primljen 17. V. 2021.

Prihvaćen 24. X. 2021.

Martina Jukić

Burghausen

martina.matic.m@gmail.com

\title{
FIGURATIVNA UPORABA RIJEČI I EKSPRESIVNOST TEKSTA
}

\section{Sažetak}

U članku se analizira kontekstno ekspresivan leksik odnosno figurativna uporaba riječi. Radi se o uporabi stilskih figura i tropa za čije je prepoznavanje i analizu potreban kontekst u kojem se javljaju, a usto utječu na ekspresivnost teksta. Za potrebe rada rabljeni su eseji (objavljeni u zbirci Sadašnjost za vječnost) i feljtoni (objavljeni u zbirci En Passant) Veselka Tenžere u kojima su, s obzirom na učestalost, obrađene sljedeće stilske figure i tropi: elipsa, personifikacija, poredba, hiperbola, metonimija, oksimoron, ironija i sarkazam. Analizom je pokazano kako figurativna uporaba riječi doprinosi ekspresivnosti teksta jer se tako koriste dodatne mogućnosti u jeziku kao sustavu kojima se stvaraju nove veze među riječima. Posebnost tih tekstova čine i autorova kreativnost, individualnost te subjektivnost u stvaranju novih neobičnih jezičnih tvorevina čije su značenje i funkcija uvjetovani uglavnom kontekstom u koje ih Tenžera smješta.

Ključne riječi: figure; figurativnost; tropi; kontekst; ekspresivnost; Veselko Tenžera; elipsa; personifikacija; poredba; hiperbola; metonimija; oksimoron; ironija; sarkazam 


\section{Uvod}

Pojam figura (lat. lik, oblik) susreće se u likovnoj umjetnosti, plesu, športu te književnosti. U književnosti, točnije klasičnoj retorici, figura „označuje osobito oblikovan govor koji se svojim izrazom otklanja od svakodnevnoga govora. Svrha je takva promišljenoga isticanja riječi slikovitije izražavanje ideja, čime bi se trebala privući pozornost publi-

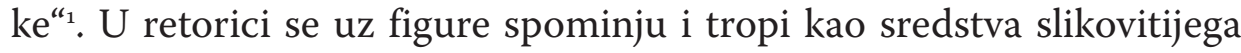
izražavanja ideja, a zbog njihova različitog definiranja - figure kao sredstva koja unose obrat u izraz jezičnih sklopova te tropa koji mijenjaju značenje riječi ${ }^{2}$ - javljaju se i različiti kriteriji klasificiranja koji polaze od drugačijega poimanja jezične norme. Figurativna se uporaba riječi ili figurativnost ${ }^{3} \mathrm{u}$ radu odnosi na uporabu stilskih figura i tropa za čije je prepoznavanje i analizu potreban kontekst u kojem se javljaju, a dodatno utječu na ekspresivnost teksta, odnosno riječ je o mnogo figurativnijemu jeziku nego što je to uobičajeno u svakodnevnoj komunikaciji. Takav se jezik može odrediti i kao jezik kojim se stvaraju slojevi značenja kojima se pristupa osjetilno, simbolično, zvučno, tj. taj jezik „dovodi čitatelja dublje u temu rada, bez da autor izričito izlaže temu čitatelju. (...) Figurativni jezik potiče čitatelja da uspostavi veze s likovima, radnjom i dubljom porukom djela koje čitatelju stvara doživljaj koji se pamti“. ${ }^{4}$

Da bi se moglo nešto reći o ekspresivnosti, potrebno je prvo odrediti pojam stilističke kategorije. U nastojanju da odredi značenje stilističke kategorije, Tošović ga uspoređuje sa stilističkim pojmom pa stilistička kategorija

... nastaje uproštavanjem, kategorizacijom, odnosno objedinjavanjem stilističkih formi, značenja i funkcija. Ona mora biti jedinstvo najmanje dviju stilističkih pojava. Razlika između ova dva izraza je u tome što je

„Figura“, Hrvatska enciklopedija, mrežno izdanje, Leksikografski zavod Miroslav Krleža, 2021., <http://www.enciklopedija.hr/Natuknica.aspx?ID=19489>, (1. X. 2021).

2 Usp. n. mj.

3 Vidi: Magdalena Nigoević - Josip Galić, „Figurativnost talijanskih i hrvatskih novinskih naslova“, Zbornik radova Filozofskog fakulteta u Splitu, god. V. (2012.) br. 5., str. 265277. Vidi i: „Figura“, n. mj.

4 „Vrste Figurativnog Jezika“, StoryboardThat, <http://www.storyboardthat.com/hr/articles/e/figurativni-jezik>, (1. X. 2021). 
stilistički pojam predstava o nekoj individualnoj pojavi, a stilistička kategorija je objedinjavanje više individualnih pojava. To znači da ista riječ može u jednom slučaju označavati pojam, a u drugom kategoriju, što stvara najveći problem u razgraničavanju stilističkog pojma od stilističke kategorije. ${ }^{5}$

Dakle, radi se o međusobno bliskim pojmovima čije se razlike određuju nijansama, a postaju vidljivije kada se navedu stilističke kategorije među kojima je najvažnija ekspresivnost ${ }^{6}$. Na sličan će način Pranjić odrediti ekspresivnost kada govori o predmetu proučavanja deskriptivne stilistike, pa će naglasiti da ta disciplina u svojoj analizi jezičnu ekspresiju

... promatra u njezinoj trovalentnosti:pojmovnoj, ekspresivnoj i impresivnoj. Ekspresivne i impresivne vrednote jezičnog izraza jesu stilističke vrednote. Deskriptivna stilistika tako je zapravo studij ekspresivnih i impresivnih vrednota, svojstvenih različitim izražajnim sredstvima kojima raspolaže jezik; ove su vrednote vezane uz postojanje tzv. stilističkih varijanata, a to će reći: različitih načina da se izrazi jedna te ista, vezane su uz IZBOR da se nešto između više mogućih načina kaže samo na jedan jedini. ${ }^{7}$

Nadalje, Rosandić i Silić ekspresivnost kao stilsku značajku dijele na inherentnu i kontekstnu. Inherentna ekspresivnost proizlazi iz same jezične jedinice, pa u tu vrstu ekspresivnosti ubrajaju deminutive, augmentative, meliorative, pejorative, hipokoristike, vulgarizme, disfemizme, žargonizme, arhaizme, onomatopeizme, frazeme i sl., dok je kontekstna ekspresivnost uvjetovana kontekstom, a obuhvaća figurativnu uporabu riječi, odnosno metaforu, metonimiju, eufemizam, ironiju, sarkazam i

5 Branko Tošović, „Stilističke kategorije“, Stil, Javna ustanova Književna zadruga Banja luka - Međunarodno udruženje, „Stil“, Banjaluka - Beograd, br. 2., 2003., str. 45.

6 Kada govori o jezičnoj ekspresivnosti, Simeon je stavlja u sinoniman odnos s jezičnom izražajnošću te navodi da je to „aktivna manifestacija, puna života i boje, koju u govoru dobivaju osobite duševne forme (želje, volja, sudovi, duševni osjećaji) kod govornika, pomoću izbora i razmještaja riječi, različitog i izrazitog izgovora, promjena u glasu itd." (RIKARD SIMEON, Enciklopedijski rječnik lingvističkih naziva, Matica hrvatska, Zagreb, 1969., str. 293.).

$7 \quad$ Krunoslav Pranjı́́, Jezik $i$ književno djelo. Ogledi za lingvostilističku analizu književnih tekstova, Školska knjiga, Zagreb, 1968. str. 50. 
druge figure kao i određene leksičko-semantičke odnose među riječima (antonimija, sinonimija, homonimija, paronimija). Jedan od sustavnijih prikaza ekspresivnosti kao stilističke kategorije dao je Tošović koji u članku donosi različita stajališta o toj kategoriji. Tako u prvome dijelu ekspresivnost određuje u odnosu na emocionalno, stilističko, izražajno, slikovito, konotativno i estetsko, u drugome dijelu ekspresivnost tumači kao isključivo stilističku kategoriju, a u trećem je promatra na razini globalne diferencijacije jezika, a usto navodi i niz vrsta ekspresivnosti kao i njihovih klasifikacija. Donekle sve navedeno objedinjuje sljedećom definicijom:

\begin{abstract}
Ekspresivnost je kategorija stilistike, lingvistike, teorije književnosti, teorije umjetnosti, estetike, logike i psihologije, genetike, koja na jezičkom planu obuhvata formalne, semantičke, funkcionalne i kategorijalne jedinice u njihovim homogenim i heterogenim odnosima, a koje odražavaju i izražavaju svjestan subjektivni, emocionalni i/li estetizirani odnos A (pošiljaoca, autora, govornog lica) prema B (primaocu, recipijentu, sabesjedniku) ili C (predmetu, sadržaju poruke). ${ }^{9}$
\end{abstract}

Dakle, u radu je analiziran kontekstno ekspresivan leksik ${ }^{10}$ koji obuhvaća figurativnu uporabu riječi, ali analizom nisu obuhvaćeni leksičko-semantički odnosi među leksemima (antonimija, sinonimija, paronimija, homonimija $)^{11}$ koji su također dio navedenoga leksika. Radi se o stilskim figurama i tropima, odnosno o elipsi, personifikaciji, poredbi, hiperboli, metonimiji, oksimoronu, ironiji i sarkazmu, a primjeri su preuzeti iz odabranih feljtona i eseja Veselka Tenžere.

\title{
1. Elipsa
}

Elipsa se najčešće definira kao ispuštanje jedne ili više riječi. Radi se o figuri konstrukcije u kojoj se izostavljanjem jednoga dijela rečenice

\footnotetext{
8 Usp. Dragutin Rosandić - Josip Silić, Osnove morfologije i morfostilistike hrvatskoga književnog jezika: priručnik za nastavnike, Školska knjiga, Zagreb, 1979., str. 164.

9 Branko Tošović, „Ekspresivnost“, Stil, sv. 3, Beograd - Banjaluka, 2004., str. 25.

10 Vidi: D. Rosandić - J. Silić, $n$. $d j$.

${ }_{11}$ Usp. Marina KatniĆ-BAKARŠIĆ, Stilistika, Ljiljan, Sarajevo, 2001., str. 225.
} 
ili više njih narušava sintaktička struktura, ali značenje rečenice u potpunosti se ostvaruje. ${ }^{12}$ Takvim postupkom ostvaruju se jezgrovitost i sažetost izraza u tekstu pa je vrlo česta figura u razgovornome i publicističkome funkcionalnom stilu, a zahvaljujući kontekstu ili komunikacijskoj situaciji, izostavljeni se dijelovi mogu bez poteškoća rekonstruirati. ${ }^{13}$ Iako se mogu izostaviti imenice i zamjenice, uglavnom se izostavljaju glagoli što pokazuju izdvojeni primjeri iz feljtona i eseja:

Nešto važno i zabrinuto, šutljivo i napregnuto, očito spoj materijalnog blagostanja i duhovnog bezizlaza. (EP, 23)

Lice krize pod maskom obilja. (EP, 33)

Sodoma i Gomora - jednom riječju. (EP, 50)

Uzbudljiva, obična, društvenosna, tužna, vesela, opora kao i mi. (EP, 78)

Stari namještaj, odstajana vina, patinirani filigrani, ulomci antike, slike starih majstora ili barem njihovih šegrta... (EP, 85)

Konfekcija i jeftini boutique, vuna i koža, košare i vrećice, taške i tašnuljci o zaglavku utegnutih, dečki u godinama. (EP, 87)

Kornjača s lakoćom leptira i leptir s temeljitošću kornjače. Slika jedne moderne katedre i modernoga novinarstva. (SZV, 116)

Slikar i pedagog, uznik i revolucionar. (SZV, 265)

Dakle, radi se o primjerima u kojima je izostavljen glagol, a koje usto odlikuje nabrajanje pa čak i gomilanje uglavnom imenskih riječi. Funkcije takvih eliptičnih konstrukcija u publicističkome stilu jesu pojačavanje i dinamiziranje iskaza, naglašavanje određenih riječi ili izraza i svjedočenje o emocionalnosti autora. ${ }^{14}$

\section{Personifikacija}

Personifikacija je figura misli koju odlikuje „pridavanje ljudskih osobina, misli, osjećaja i ponašanja kakvu predmetu, stvari, pojavi, ap-

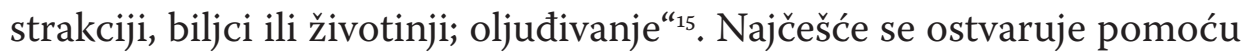

\footnotetext{
Usp. Krešimir Bagić, Rječnik stilskih figura, Školska knjiga, Zagreb, 2012., str. 92.

Usp. isto, str. 92.

Usp. isto.

Isto, str. 245.
} 
metafore, sinegdohe ili metonimije, a javlja se u pjesništvu, publicističkome stilu, reklami i dr. S obzirom na to da se radi o publicističkim žanrovima, funkcija personifikacije bit će elegantnije izlaganje i opisivanje ili će predstavljati uporište za ostvarenje prigodne komike, poetičnosti ili patosa. ${ }^{16}$ Slijedi nekoliko primjera iz feljtona i eseja:

Odlazeći potkraj kolovoza s Jadrana, učinilo mi se da je njemu potrebniji odmor negoli bučnoj gomili na njegovim obalama. (EP, 39)

Eto, iz susjedne sobe čuje se prustovski zvuk nedjeljog porculana, susret žlice i tanjura, romor prastarog rituala i zadovoljno mljackanje posvećenog hedonizma. (EP, 49)

U posljednji tren ipak je književnost našem znancu pružila ruku. (EP, 58) ... dok obračunava s nevidljivim opasnostima koje su mu pogled naoružale sumnjom i lice gorčinom. (EP, 59)

... i svakog se dana prazninom njihovih života zanjiše paučina očaja... (EP, 67)

Ako mi se ne bi zamjerile teške riječi... (EP, 71)

To je grad koji doslovce proguta poneko obližnje selo... (EP, 73)

Za vikenda Sarajevo iz „Noćnog džepa“ vadi simpozij o tekstu u estradnoj glazbi... (EP, 98)

Magnetoskop je zapravo kriv što imamo vampirsku televiziju koja nam neprestano vraća sablasti što smo ih pohranili u sjećanju - ona nas hrani prošlošću. (SZV, 99)

Teško je danas iz takva opusa izdvojiti strasti ili opredjeljenja, polemičke odluke ili pozive na raspravu. (SZV, 115)

... slobodan stih je čedo mira. (SZV, 118)

U njegovim sestinama zarobljeno je i uređeno $Z l o$, prepoznato i izmjereno i bez očiju... (SZV, 119)

A ta dogma je već počela pucati, i samosvojniji europski narodi prilagođavaju je prema svojoj mjeri. (SZV, 127)

Dugo vremena Vidrićevu poeziju objašnjavalo se posredstvom glazbe i slikarstva, što je samo potenciralo njezinu apstraktnost i posuđivalo joj privremena prepoznavanja... (SZV, 133)

Fašizam mu je došao na vrata i odveo ga u tamu... (SZV, 140)

Tako je njegov vlastiti ego progutao smisao njegova bunta i smisao svijeta kojemu je pripadao... (SZV, 165)

Usp. isto, str. 247. 
Mozak bdi nad porazom tijela i tješi samrlu sadašnjost, obećavajući joj kao djetetu veliko sutra, jedino vrijeme svake provincije. (SZV, 166)

... naravno ako ravnodušnost nije pokopala zanimanje za umjetnost riječi. (SZV, 174)

Iako se personifikacija određuje uglavnom kao figura oljuđivanja, ponekad se taj odnos ostvaruje i kada se neživim stvarima pridaju osobine biljaka ili životinje, primjerice: ... s maskom bajke na licu tek propupale pohlepe (EP, 35); Ako taj prostor ne zanima naše uvažene pjesnike, zašto bi, je li, poezija otežavala mriještenje novca (EP, 42).

Kao što je već spomenuto, glavne funkcije personifikacije u obrađenim tekstovima jesu komičnost, patos te vrlo često i ironična dosjetka, čime se postiže višedimenzijalnost teksta, odnosno tako se aktiviraju dubinske strukture $\mathrm{u}$ jeziku (to je osobito vidljivo $\mathrm{u}$ ironiji, sarkazmu, metafori i metonimiji), a sve skupa doprinosi ekspresivnosti tekstova.

\section{Poredba}

Poredba je figura riječi (trop) u kojoj se bića, predmeti, stvari i pojave povezuju na temelju skrivenoga ili pripisanoga svojstva, zasniva se na analogiji, ali čuva izvorni smisao riječi ${ }^{17} \mathrm{U}$ hrvatskome jeziku poredba se najčešće ostvaruje pomoću veznika kao ili prijedloga poput, a ponekad tu ulogu mogu imati i glagoli sličiti, nalikovati, pridjevi sličan, nalik, jednak ili prilozi slično i isto. Kao stilska figura najuobičajenija je u književnoumjetničkome stilu, no vrlo je česta i u publicističkome stilu, osobito u novinskim žanrovima. Prema Bagiću u „novinarskom jeziku poredba je neizostavan stilski rekvizit. Njome se vuku očekivane i neočekivane paralele, postiže atraktivnost, mistificira tema, iskazuje autorova afektivnost, aludira na usmenu i visoku kulturu"18. Upravo takvu funkciju i imaju poredbe u Tenžerinim tekstovima, osobito one koje su neočekivane, s tim da ih odlikuje i komičan učinak čime se dodatno pojačava ekspresivnost feljtona i eseja. Navodimo nekoliko primjera:

Usp. K. BAGIĆ, $n$. dj., str. 256.

${ }_{18}$ Isto, str. 256. 
... svijetli oko vaše glave aura poraza kao „Podravkin“ kolut oko slavnoga pijevca. (EP, 22)

... svaka želja izgleda poput orla u kavezu za kanarinca... (EP, 42)

... vjerojatno i sami svjesni, poput nesretnog Fausta, da znanost loše nadomješćuje užitak. (EP, 50)

Okolo sve neki padobranci, s bisagama à la John Wayne i sa desetak ovećih džepova... (EP, 68)

... i tijelu koje kipi kao nabujak od karfiola... (EP, 96)

On sija poput uštapa kad „njegov“ igrač raščereči protivnika, a kune kao Job kad njegov miljenik tresne u travu. (EP, 123)

... on se gubi u pomalo herojskoj pozi u onim zonama književne povijesti gdje nam se nekako prirodnim čini da spadaju književni mučenici, kao historiografski folklor. (SZV, 122)

... to jest od mračnih dogma koje svijet uzgaja strpljivo poput krumpira. (SZV, 131)

Zatvorena situacija Careve kraljevine moćna je metafora represije, u kojoj se ljudi poput ameba, dijele u sve sitnije oblike. (SZV, 141)

... tipus koji je poput gromobrana upio sve njihove strahove od života i postao ono što su oni izbjegli s užasom... (SZV, 142)

... ugurati Ujevića u takvu koncepciju nacionalne književnosti nalikovalo bi guranju slona u dječja kolica. (SZV, 144)

... koristeći bogate emocionalne slojeve te pjesme kao „nosioce“konkretnih historijskih značenja. (SZV, 147)

... pravda se tu, kao u antičkoj drami, ispunja kroz tragediju. (SZV, 153)

... nego proučava metriku, koja se često s hrvatskim jezikom slaže kao pas s mačkom. (SZV, 161)

... zajedno s Petrom Zrinskim, samovao na svome tronu, kao higijenizirani znak pobune... (SZV, 153)

... čovjek se poput Rodinova mislioca savija u krug materije i osjeća čisti plač tijela... (SZV, 166)

Vratimo se pitanju koje se razmnožava poput amebe: što mislite o kritici? $(\mathrm{SZV}, 173)$

... jer neće smetati toj divnoj književnosti da nesputano raste, kao čarobni grah onih holivudskih komičara. (SZV, 173)

Određene poredbe zbog neočekivanih veza među riječima ili upućivanjem na druge neobične sadržaje ili svjetove $u$ odnosu na prvi 
poredbeni korelat (kao što je to primjer: Foreman je spor $i$ snažan poput velikih rijeka s američkoga Juga, Ali je brz kao zlo na periferiji gradova u kojima je rastao.; EP, 140) izazivaju začudnost kod čitatelja, a u nekima se ostvaruje i humor koji je najčešće rezultat autorove subjektivnosti pri čemu autor računa s čitateljevim iskustvom ${ }^{19}$. Primjerice:

... banalan sam kao magarac u kraljevskoj ergeli arapskih pastuha... (EP, 25)

... mačak koji voli sudjelovati u svojem dijelu svijeta, ali koji svaki puta pretrpi u tri minute više negoli što su sveci trpjeli u desetljećima. (EP, 28)

... gdje se potomci bivših kirijaša zagledaju izmedu sebe, kao što su njihovi preci zagledali stoku. (EP, 93)

Dočekao ga je kao seljak koji kostima osjeća jesensku oluju... (SZV, 118)

... u kojem se pisanjem mjere ulomci življenja, s perom kao instrumentom totalnog sudjelovanja u ovome i ovakvome životu... (SZV, 125)

Kao da je pisac pripremao svoje orude na materijalima prikladnijim za literarnu vježbu, negoli za epska iskušenja. (SZV, 156)

Stilski osobito markirane poredbe jesu one koje su nagomilane. Iako se gomilanje određuje kao navođenje većega broja riječi koje su iste morfološke vrste, a pripadaju različitim semantičkim poljima među kojima postoji semantička kohezija ${ }^{20}$, tu definiciju ne možemo primijeniti u ovome slučaju jer se radi o leksičkoj razini, a poredba je kontekstualno uvjetovana. Dakle, gomilanje se odnosi na navođenje dviju ili više različitih poredbi ili je riječ o jednoj poredbi unutar koje se navodi više poredbenih korelata i to najčešće kada se radi o drugome članu poredbe. Slijedi nekoliko primjera takvih poredaba:

Stara, čangrizava dama sve to prima, hladna poput engleske udovice kad joj kraljica predaje muža u plišanoj kutijici, daleka kao grob kolonijalnog vojnika... (EP, 52)

Učas sve obrsti kao koza, progrize kao skakavac, opustoši kao tajfun. (EP, 66)

\footnotetext{
19 Usp. Marko Samardžıja, Piščev izbor: prinosi (leksiko)stilistici i tekstologiji hrvatskog je$z i k a$, Pergamena, Zagreb, 2003., str. 70.

20 Usp. isto, str. 52.
} 
... mljaskajući žvake poput teladi u vrijeme preživanja, glasan do besvijesti, mentoliziran, aseptičan, upakiran poput špecerajskih artikala za neki užasno važan sajam. (EP, 89)

On je pri tome precizan poput urara, hladan poput znanstvenika i nadahnut poput pjesnika. (SZV, 129)

Kao da slave nikad nije ni bilo, oko pisca su se opet stegle tamne draperije tišine i zaborava. Slava bijaše gotovo nešto poput incidenta, luksuzne epizode, slučaja. (SZV, 157)

... Fran Krsto Frankopan, kao u orfičkoj teogoniji, otkriva eros kao sveprožimljuće načelo života. (SZV, 165)

Uz već neke od navedenih odlika poredbe, u izdvojenim primjerima primjećujemo i popriličan broj i takvih poredbi kod kojih drugi poredbeni član čini jedna rečenica, primjerice: „U tolikim radovima našoj se kritici Krleža pričinjao poput meteorita koji se srušio odnekud iz svemira u panonski krajolik." (SZV, 136) ili „On će se, naravno, držati ravnodušno, kao neki glasoviti učenjak kad ga primaju za počasnog člana u kakvu provincijsku Akademiju" (EP, 53). Takav postupak nije uobičajen u književnoumjetničkome stilu odnosno njegovu poetskom podstilu da bi se ispoštovale granice koje nameće stihovna struktura pjesme, što ne postoji u proznome tekstu pa u tome slučaju autor ima potpunu slobodu u produživanju drugoga člana poredbe, a samome tekstu daje osobnu notu.

\section{Hiperbola}

Hiperbola kao figura misli označava pojačavanje izraza do njegove krajnosti ${ }^{21}$, bilo da se radi o uvećanju ili umanjivanju neke vrijednosti, odlike, svojstva bića, stvari, emocija ili pojava. To je figura koja se javlja od samih početaka, dakle razvojem retorike, kao univerzalija i zastupljena je u svim područjima čovjekova djelovanja, dakle i u svim funkcionalnim stilovima, a osobito u publicističkome čiji su novinski žanrovi utemeljeni na hiperboli. Najčešće se ostvaruje pomoću poredbe,

${ }^{21}$ Usp. Ranko Bugarski, Uvod u opštu lingvistiku, Čigoja štampa - XX vek, Beograd, 2003., str. 232. 
metafore, metonimije, sinegdohe, gradacije i dr., a konotacije koje veže uza se pretežito su pozitivne. ${ }^{22}$

Kada se radi o publicističkome stilu i njegovim žanrovima, ponekad te konotacije mogu biti i negativne pa humor kadšto prelazi u sarkazam, npr. „Za utjehu onima koji žive od neizvedenih, kadikad tako ćaknutih rješenja, mogli bismo raspisati natječaj, s pristojnim obeštećenjem, za prostorno uređenje Velebita. Makete po mogućnosti u naravnoj veličini. Kad se to završi, mogli bismo krenuti i s projektom obnove Panonskog mora." (EP, 75); „Stanujete na primjer u Dubravi i umjesto da kući idete (čekaju vas i vele da uvijek kasnite) 'jedanaesticom' pokraj Maksimira, vi se zaputite preko Tokija (EP, 40)ili pak „Naravno, riječ je o našim piscima i našoj književnosti koja je ostavila netaknuta golema $i$ stravična prostranstva svakodnevice u kojima se sve više gubimo..." (SZV, 168).

Sljedeći primjeri hiperbole izdvojeni iz feljtona i eseja pokazuju autorovu domišljatost, originalnost te osobito poznavanje jezika i njegove strukture:

...on čak prezire brata izgubljenoga u masi koji, $s$ dvije girice lirske banalnosti, pokušava nahraniti duhovnu glad oceanskih dimenzija. (EP, 40)

A priroda je tu, prastaro nemoderno srce traži svoje, potrebno je tone nježnosti da bi se umekšali opori rubovi svijeta. (EP, 15)

...i obećajete sami sebi da ćete, makar plivajući, prijeći u sjeverni dio grada, gdje su stropovi visoki i gdje jedna popušena cigareta ne simulira požar. (EP, 46)

Nekako se sve bojim da nemam ništa od toga što znam da je Tiahuanaco gradić u zapadnoj Boliviji, kad su prometne komunikacije takve da nisam siguran da ću još koji put dospjeti do Ćúcerja. (EP, 105)

Klasični je muškarac pretrpio u naše doba dva strateška poraza: u spavaćoj sobi i u kuhinji. (EP, 165)

A još da im vlastiti narod nema tako groznu prošlost, da se bolje ponašao posljednjeg tisućljeća, gdje bi im bio kraj! (EP, 187)

To je zlo kojemu ne možeš remboovski okrenuti leđa i emigrirati u egzotiku, jer kopa tvoje oči, bode tvoje tijelo, mokri po tvojemu ponosu, baca bombe u tvoju intimu. (SZV, 118)

${ }_{22}$ Usp. K. BAGIĆ, $n$. dj., str. 140. 
Tinu je trebao glagol za ona beskrajna lutanja oceanima jezika, za euforične plovidbe kroz vrtloge duha, gdje je stvarni život bio tek dosadna luka u kojoj se pravi mornari opijaju. (SZV, 142)

Nikola Šop jedan je od tih astronauta u bezdanu čovjekove nutrine koji svakim otkrićem potvrđuje da je čovjek kao i svemir beskrajan. (SZV, 152)

Do jučer zanemareni pisac odjednom postaje medijska zvijezda, praćena lavinom kritičarskih laski i intervjua, studijskih rasprava $i$ eseja. (SZV, 156)

Njegovo pjesništvo polako prestaje biti slavljeničkim pridjevom i postaje imenicom kulture. (SZV, 162)

Unatoč tomu što nije izdvojen velik broj primjera, predstavljena građa jasno ukazuje na slikovitost i jezičnu dosjetljivost autora čime se tekst diže na jednu višu razinu, koja čitateljima predstavlja izazov ili zahtijeva napor u odgonetavanju veza na kojima se temelji hiperbola, a samim time i u razumijevanju misli i stavova koje je pisac izložio u feljtonima i esejima.

\section{Metonimija}

Metonimija je „zamjenjivanje jedne riječi drugom na temelju njihove logičke bliskosti, vremenske ili prostorne povezanosti“ ${ }^{\text {“2 }}$. Te su veze najčešće konvencionalne, a odlika su uglavnom govorne komunikacije i nastaju kao rezultat ekonomičnosti izraza. ${ }^{24}$ Različiti autori navode i različite odnose ${ }^{25}$ među tim vezama pa se, s obzirom na brojnost tih veza, razlikuju i vrste metonimije (P. Fontanier govori o devet vrsta, L. Zima o deset, K. Begić o dvanaest vrsta, a H. Morier nalazi preko trideset vrsta metonimije,).

Primjeri metonimije iz feljtona i eseja odraz su autorove osobnosti i vještine u stvaranju jezičnih veza za koje je ponekad teško naći logičku

\footnotetext{
${ }^{23} \quad$ Isto, str. 199.

24 Usp. isto, str. 202.

25 O odnosu metonimije i sinonimije vidi: MARIO BRDAR, „Metonymic chains and synonymy“, Fluminensia, Rijeka, god. XXVII. (2015.) br. 2., str. 83-101.
} 
bliskost ili povezanost pa stoga nije moguće u njihovoj klasifikaciji dosljedno slijediti neku od gore navedenih podjela metonimije. To se osobito odnosi na određene primjere u kojima su članovi metonimije kontekstualno uvjetovani i razlikuju se brojem sastavnica (npr. „Dovoljno je pogledati dva posljednja kola edicije Pet stoljeća hrvatske književnosti i vidjeti kako smo doslovce pošemerili: to je bankrot svih kriterija i pravi promiskuitet vrijednosti."; SZV, 144) pa će klasifikacija primjera izostati. Oni primjeri u kojima je nejasno što je metonimija odnosno na što se odnosi, bit će popraćeni kratkom napomenom.

Erotika, pornografija, kič - eto Oca, Duha i Sina u prvoj molitvi seksualne kontrarevolucije... (EP, 13)

Treba li i reći da je to slika gotovo cijeloga globusa! (EP, 40)

Upravo idealan trenutak za pjesnika da odbaci isposničku halju desupstancijalizirana jezika i posudi pero i glas onima koji su trebali svoju pjesmu. (EP, 41)

I taj konfekcionirani Janus, junak EPP-a i miljenik svakovrsnih monopola, majstor u relativiziranju morala, ubrzo je naučio vješto baratati društvenim lozinkama i šifrirati svojim žiro-računom vlastitu pohlepu kao imperativ vremena. (EP, 43; U prvome se dijelu misli na estradne zvijezde, a posljednji se primjer - društvene lozinke - odnosi na obraćanje pravim osobama, ulagivanje da bi se došlo do cilja.)

Pogađate, riječ je o onim prognanicima iz raja, o onim izraslinama iz sjemena Adamova što se zovu podstanari. (EP, 47)

Pehist nariče kao Timon Atenjanin u šumi, sve dok ne zgrabi nagradu koju mu nitko ne uskraćuje, jer je on kao u Indiji naša sveta krava, s podjednako tužnim pogledom i ništa manjim apetitom. (EP, 55)

I što god muškarci uradili u tom prokletom životu, kako god to bilo veliko i značajno, uvijek će naići neka guzica koja će od njih napraviti početnike. (EP, 80)

Budući da dosad, koliko mi je poznato, nitko nije ni pisnuo protiv te kulturne segregacije građana Agrama, razumljivo je da se golema ozlojađenost usmjerila onamo gdje je to bilo najmanje opasno: na Meštrovića i Mimaru. (EP, 84)

Drugo je lice u ovoj jednočinki strasti - Zagreb. Nije da se hvalim kao skromni žitelj Agrama, ali to je jedan od najparadoksalnijih gradova na svijetu. (SZV, 9o) 
Tako je nastalo sijaset klišeja, uvijek prikladnih za uporabu, kako kome odgovara: revolucionarni grad, purgerska utvrda, bijeli Zagreb, do najnovijih, prekosavske spavaonice, urbana pustinja itd. (SZV, 9o)

Katodna naiva svake nas večeri gotovo raznježi kad hrpica gušavih kontinenata, u formaciji izgladnjelih leghorna, navali u naš elektronski kokošinjac; pretvaramo li se to svi u kokoši? (SZV, 101)

Lupetina pod batinama propovijeda nove ideje osuđenicima, a Vlačić na sveučilištu filološki rastvara dogme nastale iz Biblije, kojih je posljednja argumentacija bila u rukama mučitelja u kukuljicama. (SZV, 108)

Pola milenija dijeli nas od smrti na Medvedgradu hrvatskog latinista Ivana Česmičkog ili Iana Pannoniusa (1434-1472). (SZV, 111)

Mantija baš i nije najbolje forma pjesnikovanja, a biskupska stolica i ugarski dvor trebaju više prijetvorna diplomata negoli iskrena poetu. $(\mathrm{SZV}, 112)$

On je, takorekući, bez strane svijeta, osim ako to nije jug, ta vječna pozornica siromaštva, sunca, borbe i gladi. (SZV, 127)

$\mathrm{S}$ razloga satrapske cenzure, on svoju Makedoniju zove Povardarje, a kritičke postulate Todora Pavlova i "teorije odraza" uzima kao aksiome. (SZV, 147)

Naskoro će u Engleskoj, domovini velikih pjesnika, izaći knjiga tih poema, što je priznanje ne samo Šopu nego i ponos za hrvatsko pjesništvo. $(\mathrm{SZV}, 150)$

Bijaše to utoliko teže što se mrki urotnik pokazao mekoputnim ljubavnim pjesnikom, lascivim i za dvadeseto stoljeće. (SZV, 163; Riječ je o F. K. Frankopanu.)

Tako se jedan stari zanat podijelio, kako sam nedavno primjetio, na pisca koji je prihvatio sve rizike svojega posla i književnika koji bi da obnovi poslanje u funkciji „viših“, izvanknjiževnih ciljeva, što u praksi znači u funkciji moćnih institucija. (SZV, 171)

I gotovo prestao pisati, što se osobito zamijetilo jer su mladi ljudi, ti vječni mučenici kritike na početku puta, okrenuli književnosti leđa. (SZV, 172)

Već je navedeno da se metonimija temelji na sličnosti i povezanosti pojmova, stvari, pojava i sl. i to je očito i prosječnu poznavatelju tih veza. Međutim, kako je velik broj izdvojenih primjera kontekstualno uvjetovan, te veze nisu tako očite pa u njima autor navodi i član koji se inače izostavlja u metonimijskome odnosu i član koji je nastao na 
temelju metonimije, radi boljega razumijevanja teksta, kao što je to u primjeru „Zasut je jedino suvremenim mitovima, tim grandioznim kompenzacijama šarenih korica, uz koje tone u san“. (SZV, 175)

\section{Oksimoron}

Oksimoron se ubraja u figure konstrukcije, a riječ je o figuri u kojoj se međusobno povezuju semantički suprotni pojmovi. Kao stilsko sredstvo najčešće se javlja u književnoumjetničkome, publicističkome i razgovornome stilu. Učinkovito je sredstvo kada se želi iznenaditi, začuditi ili privući pozornost na nešto pa se zbog toga često rabi u naslovima knjiga (Zimsko ljetovanje, Mala velika knjiga o sobnim biljkama, O učenom neznanju) ili novinskih članaka (Mala velika jahta). ${ }^{26}$

Funkciju začudnosti, apsurdnih pojava i privlačenja pozornosti ima oksimoron u feljtonima i esejima, primjerice: ... došla je verificirati muškost žene i ženskost muškarca (EP, 63); ... zaboravimo li inerciju kulturne povijesti tipa „veličina malenih“... (EP, 87); ... otvorene su rasprave o „važnim nevažnostima“ unutar tog djela... (SZV, 126); ... koju gradimo i dalje na Barčevoj „veličini malenih“... (SZV, 144)

Ponekad se oksimoronom smatraju i neki sinestezijski spojevi (psihološki oksimoron) ili odnosi koji se stvaraju među riječima, a logički su neodrživi (contradictio in adiecto) ili pak neki postupci u filozofiji kojima se naglašavaju suprotnosti u svijetu (coincidentia oppositorum - podudaranje oprečnosti) ${ }^{27} \mathrm{U}$ tome kontekstu može se govoriti o oksimoronskome odnosu i u sljedećim primjerima:

Dedić postaje njezinom blistavom marginom... (EP, 42)

To je golemi orkestar tišine, na bezglasnom koncertu, s najvećim uspjehom ako ga „publika“ uopće ne čuje. (EP, 47)

... predan je živom maštovnom spoznavanju nepoznatih svjetova... $(\mathrm{SZV}, 150)$

... odvijao se bez zastoja i žalosno uspješno. (SZV, 168)

\footnotetext{
26 Usp. K. BAGić, $n . d j$., str. 210.

27 Usp. isto, str. 210.
} 
Dakle, radi se o dubinskim vezama među riječima u kojima se u odnos stavljaju leksemi koji su nekim od svojih značenja međusobno oprečni.

\section{Ironija}

Ironija je figura misli u kojoj se „govori posredno ili suprotno od onoga što se kani kazati - kori hvaleći, hvali kudeći, prezire diveći se, hini neznanje, svjesno prešućujeili kaže manje nego što se očekuje ${ }^{\text {"28 }}$. Njome izraz postaje snažniji i smatra se odlikom inteligentnoga i visokoga društva, česta je u svakodnevnoj komunikaciji, književnosti, publicistici, filozofiji i promidžbi. Ironija nije samostalna figura i najčešće se ostvaruje preko drugih stilskih figura: antifraze, hiperbole, litote, paradoksa, igre riječima i dr. Zbog svoje britkosti i afektivna naglašavanja često se koristi u žanrovima koji imaju polemičan karakter, a tada vrlo često prelazi u sarkazam (zajedljiva, zlobna ironija) ili cinizam (drska ironija). ${ }^{29}$ Slijedi nekoliko primjera iz feljtona i eseja u kojima je Tenžera ironijom izrekao pohvalu, mada je mnogo veći broj primjera u kojima mu je ironija poslužila za kritiziranje. Tada ona uglavnom prelazi u sarkazam ili cinizam, a vrlo je često rabi kako bi naglasio apsurdnost određenih pojava u društvu:

Kad čovjek dobro razmisli, vidi ga u svima onim slavnim bitkama koje smo ipak na kraju izgubili, premda je profesor povijesti našao i drugih razloga. (EP, 53)

Za razliku od Sokrata, koji je bos ugazio u trnje i digao paklensku larmu od koje se neprijatelju sledila krv u žilama, brljavko je jurio svuda okolo da već jednom pronađe to trnje na koje će nagaziti, pa rekao: jeste li vidjeli, nemam sreće! (EP, 53)

Najviše se dakako slavi ona poznata filozofija, da nije važno kako čovjek izvana izgleda, važni su duša i srce te, vjerojatno, gemišt koji je također "unutra“. (EP, 77)

Prosječan stan je u nas vrlo malen a prosječan namještaj golem, tako da prosječnu Zagrepčanku možete prepoznati na plaži po modricama na bedrima, koje je dobila udarajući o kauč, o štednjak, o stol... (EP, 77)

${ }_{28} \quad$ Isto, str. 158.

29 Usp. isto, str. 161. 
Lezbijke na jednu stranu, pederi na drugu, nešto dalje raspuštenice, a oko nas ona dva-tri stalka mi prolaznici koji smo od sve silne mudrosti Istoka priznali samo vodku. (EP, 82)

I opet ispravak: masa divne publike, bujice mlađarije, ljudi što žele sudjelovati u Događaju, kojima moralna sitnost, tako svojstvena dijelu naše „inteligencije“, ne priječi da komuniciraju s nečim što ih nadilazi. (EP, 87) Uzmognu li tradicionalna kultura i njezine ustanove proizvoditi takve dogadaje, eto nas na pragu dugo očekivana kulturnog zamaha. (EP, 88)

Egoizam je ipak najstarija ljudska strast, koja se usto najlakše maskira društvenim svetinjama. (EP, 94)

Najnovije remek-djelo televizijske naive svakako je špica zagrebačkog „Dnevnika“. Kompjutorska animacija jedva da je maskirala idiličnu seosku inspiraciju. (EP, 101)

Kad su Englezi vidjeli koliko ih stoji plovidba samo u jednom smjeru do Falklandskog otočja, porasli su izgledi za mirno rješenje spora s Argentinom. Ratovati uz današnje cijene, svašta! (SZV, 103)

Čovjek koji je doktorirao u dvadeset trećoj godini (biografska i patološka pozadina Maupassantovih djela) jedva da je danas zamisliv, kad umorni četrdesetgodišnjaci tek magistriraju. (SZV, 114)

Versifikatorima u klasičnom smislu te riječi nadošla oluja pokidala je strune, dok su ostali veličinom fraze pokušavali dosegnuti veličinu zbilje: kakav beznadan napor! (SZV, 117)

U našoj je literaturi oduvijek bilo neusporedivo više književnika nego pisaca, i zato je ta literatura tako inertna, tako trošiva i tako lagan plijen zaborava. Tu se ne pišu, nego prave knjige, prema ovim ili onim obrascima, trendovima ili modama. (SZV, 123-124)

To je zavelo ponekoga kritičara da ga katologizira u realiste, jer u našem prostoru tvrdoglavo istrajava zabluda da je "realnost“ jasna kao kupus $i$ čitliiva poput seoskoga kalendara. (SZV, 130)

U svakom divljenju imade više ljubavi nego lucidnosti: jezik divljenja oduvijek je tragao za augmentativima i alegorijom. (SZV, 135)

Od darovitosti kritičara zavisilo je hoćemo li u određenom trenutku apsolutizirati Krležu kao dramatika, romanopisca, pjesnika Balada..., polemičara... Golemi opus još nas je više zbunjivao: ta, valja odvojiti cijelu jednu godinu života, ne radeći gotovo ništa drugo, da bi se iščitala njegova djela. (SZV, 136)

U takav duhovni i politički prostor ulazi mladi Cesarec kao atentator i, dakako, robijaš. (SZV, 140) 
Odjednom je pred užasnutim očima intelektualnih ljenivaca izronio tovar knjiga, iz kojih se naziralo ne samo lice velikog pjesnika nego i visoko čelo prvorazrednog intelektualca, a takvi nisu baš na cijeni. (SZV, 142)

U zemlji s 20\% nepismenih i nebrojeno polupismenih oduvijek su se ljudi dijelili mimo djela, pretpostavljajući estetici neku grupnu opredijeljenost uglednih muževa. (SZV, 157)

Kao pokajnik, umišljao je da je mnogo griješio, a možda je u dnu duše vjerovao da je grešan koliko i njegovi krvnici, i da mu kao i njima predstoji velika karijera na tamnijoj strani neba. (SZV, 164-165)

Zasuti smo naprosto lopatama stihova u kojima, ako smo strpljivi, možemo redovito odčitati himnu samome sebi i pamflet svijetu u kojemu kraljuje briljantno Ja. (SZV, 174)

\section{Sarkazam}

Sarkazam se određuje kao zajedljiva ironija kojom se želi obezvrijediti ili ismijati nekoga ili nešto. ${ }^{30}$ Sarkazmu je najčešća funkcija oštra kritika nekih pojava u društvu, a u tekstu izaziva začudnost. Često se poseže za prenesenim značenjem, najčešće u obliku metafore, da bi se sačuvala jezična jezgrovitost. Kod Tenžere je to čest stilski postupak kojim se tekst diže na višu razinu, a očituje se autorova vrsnost i dosjetljivost u uporabi i vladanju jezičnim mogućnostima te britkost i oštrina kojom kritizira određene društvene pojave, osobe, a ponekad su te zajedljivost i porugljivost upućene njemu samomu. To je osobito vidljivo $\mathrm{u}$ feljtonu o podstanarima, jer je i sam bio podstanar cijeli život, s naslovom u imperativnome obliku - Ustajte prezreni na svijetu - primjerice: „Podstanar je stoga detektor snova jednoga društva, katapult za skok iz stvarnosti i afrodizijak za materijalno impotentne. Zahvaljujući njemu, privredni kriminal je manji nego što bi bez njega bio, on je krvavo platio otvorene granice $i$ Ponte rosso (prilog demokraciji), vikendice $i$ pune izloge dućana, vladinog klokana cijenâ i općinskog vuka poreza." (EP, 47) Navodimo još nekoliko primjera iz oba žanra u kojima vrlo rijetko

3o Usp. M. KATNiĆ-BAKARŠIĆ, $n$. $d j$., str. 281. 
sarkazam dolazi samostalno, obično je sarkastičan ton teksta pojačan metaforom ili metonimijom:

Čak mu ni roditelji nisu bili siromašni, čime je i njegova biografija, barem u ovim stranama, postala užasno jadnom. Ako ništa drugo, ostao je bez nesretnog djetinjstva, kojim se mnogi od nas ponose, a da i ne znaju zašto. (EP, 56)

Za razliku od usidjelice, kandidirao se za javnu osobu samo jedanput, prilikom kampanje protiv pušenja, kad je na žalost i pobijedio, tako da danas nemate čime raskužiti autobus kad putujete. (EP, 61)

Matoš je jedan od rijetkih koji je uspio da se o njemu i nakon smrti loše govori. $_{(\mathrm{EP}, 69)}$

Da se slikaju turisti i ekskurzije, osobito oni među njima koji pišu ponajbolje zadaće, jer do nekih godina života nije se opasno igrati Matoša. (EP, 71)

Gotovo cijeli svijet zahvatila je manija trčanja. Nekoć pretrpane karijerističke staze zamjenjuju pomalo one atletske. Na prvima se lako stizalo do pokala u obliku infarkta ili čira na želudcu, a druge nam obećavaju da ćemo još jednom moći odjenuti ženidbeno odijelo. (EP, 76)

Kult tikvana, koji u društvu šuti a na sastancima benavi, projicira se polako u nacionalni tip na medijima. Možete ga vidjeti čak kao voditelja u važnijim emisijama, a na vjenčanju su mu kumovi morali šapnuti što da odgovori matičaru. (EP, 99)

Hegelijanska po impulsu i čedo velikih improvizatora, koji su već svijet ujedinili na regalima knjižnica i u vatrometima književnih razgovora. Znanost koje je u Hrvatskoj Ivo Hergešić roditelj, uz priznanje i nekolicini babica. (SZV, 115)

Bio je, zapravo, rasan impresionist, u klasičnom smislu tog pojma, koji još nije uspio postati ruglom $u$ „kategorijalnim aparatima“ sipljivih akademskih jalovaca. (SZV, 124)

Obojica su umrli od iste boljke, raka na grlu, učenik u kasnijim godinama od učitelja: cigarete, cigarete, cigarete. Pero i cigareta. Ni jedan veliki hrvatski pisac nije ni sa čime drugim ni raspolagao. (SZV, 143)

Kao što izdvojeni primjeri pokazuju, sarkazam je Tenžeri poslužio kako bi uputio konstruktivnu kritiku društvu ili nekim pojavama u društvu te kritiku u odnosu prema nekim osobama, uglavnom književnicima, koji nisu dobili zasluženo mjesto u znanosti i kulturi za razliku od nekih „akademskih jalovaca“. 


\section{Zaključak}

$\mathrm{Na}$ osnovi analiziranoga korpusa možemo zaključiti da uporaba stilskih figura i tropa oblikuje poseban jezik, različit od jezika svakodnevne komunikacije, pa onda govorimo o figurativnome jeziku. Takav jezik doprinosi ekspresivnosti teksta jer se tada koriste dodatne mogućnosti kojima se stvaraju nove veze među riječima, a njihovom se kombinacijom oblikuje visoki stil tekstova feljtona i eseja. Posebnost tih tekstova čine i autorova kreativnost, individualnost te subjektivnost u stvaranju novih neobičnih jezičnih tvorevina čije su značenje i funkcija uvjetovani uglavnom kontekstom u koje ih Tenžera smješta.

\section{Literatura}

- BAgić, Krešimir, Rječnik stilskih figura, Školska knjiga, Zagreb, 2012.

- Brdar, Mario, „Metonymic chains and synonymy“, Fluminensia, Rijeka, god. XXVII. (2015.) br. 2., str. 83-101.

- Bugarski, Ranko, Uvod u opštu lingvistiku, Čigoja štampa - XX vek, Beograd, 2003.

- „Figura“, Hrvatska enciklopedija, mrežno izdanje, Leksikografski zavod Miroslav Krleža, 2021., <http://www.enciklopedija.hr/Natuknica.aspx?ID=19489>, (1. X. 2021).

- Katnić-Bakaršić, Marina, Stilistika, Ljiljan, Sarajevo, 2001.

- Nigoević, Magdalena - Galić, Josip, „Figurativnost talijanskih i hrvatskih novinskih naslova", Zbornik radova Filozofskog fakulteta u Splitu, god. V. (2012.) br. 5., str. 265-277.

- Pranjić, Krunoslav, Jezik i književno djelo. Ogledi za lingvostilističku analizu književnih tekstova, Školska knjiga, Zagreb, 1968.

- Rosandić, Dragutin - Silić, Josip, Osnove morfologije i morfostilistike hrvatskoga književnog jezika: priručnik za nastavnike, Školska knjiga, Zagreb, 1979. 
- Samardžıja, Marko, Piščev izbor: prinosi (leksiko)stilistici i tekstologiji hrvatskog jezika, Pergamena, Zagreb, 2003.

- SimeOn, RiKARD, Enciklopedijski rječnik lingvističkih naziva, Matica hrvatska, Zagreb, 1969.

- Tenžera, Veselko, En Passant, Znanje, Zagreb, 1978.

- Tenžera, Veselko, Sadašnjost za vječnost - izbor iz djela, Zima, ZDRAVKO (prir.), Naklada Ljevak, Zagreb, 2005.

- Tošović, Branko, „Stilističke kategorije“, Stil, Javna ustanova Književna zadruga Banja luka - Međunarodno udruženje, „Stil“, Banjaluka - Beograd, br. 2., 2003., str. 45-63.

- Tošović, Branko, „Ekspresivnost“, Stil, Javna ustanova Književna zadruga Banja luka - Međunarodno udruženje, „Stil“, Banjaluka - Beograd, br. 3., 2004., str. 25-61.

- „Vrste Figurativnog Jezika“, StoryboardThat, <http://www.storyboardthat.com/hr/articles/e/figurativni-jezik>, (1. X. 2021). 
Original scientific article

Received on May 17, 2021

Accepted on October 24, 2021

Martina Jukić

\section{FIGURATIVE USAGE OF WORDS AND EXPRESSIVENESS OF THE TEXT}

\section{Abstract}

The paper analyzes contextually expressive lexis or figurative usage of words. It is about usage of figures of speech and tropes, whose recognition and analysis requires context in which they appear and at the same time effect the text expressiveness. Essays (published in the collection Sadašnjost za vječnost) and feuilletons (published in the collection En Passant) by Veselko Tenžera, were used for the purpose of this paper. Following figures of speech and tropes were analyzed in terms of their frequency: ellipsis, personification, comparison, hyperbole, metonymy, oxymoron, irony and sarcasm. The analysis shows that figurative usage of words contributes to expressiveness of the text, because in this way additional possibilities are used in language as a system for making new connections between words. The uniqueness of these texts is the author's creativity, individuality and subjectivity in creating new unusual language forms whose meaning and function are conditioned mainly by the context in which they are put by Tenžera.

Keywords: figures; figurativeness; tropes; context; expressiveness; Veselko Tenžera; ellipsis; personification; comparison; hyperbole; metonymy; oxymoron; irony; sarcasm 